\title{
SOCIAL SPACE AS AN OBJECT OF GEOGRAPHICAL RESEARCH AND THE ROLE OF COMMUNICATIONS IN ITS CONSTRUCTION
}

\author{
Serhii PUHACH \\ Lesya Ukrainka Volyn National University, Ukraine \\ puhachserhiy@gmail.com
}

\begin{abstract}
The article attempts to analyze the concept of "social space" from the standpoint of geography. Geographers understand space mainly as a "tabula rasa" on which human society functions and develops. However, the requirements of today require a deeper understanding of the essence of human, the study of internal motives of human activity. The category "social space" is used for this purpose. The aim of the study is to systematize scientific interpretations of the concept of "social space", to determine its properties and characteristics in Ukrainian and foreign scientific literature. The main task is to determine the role of communications in the formation and functioning of social space.

Geographers understand social space primarily as a part of geographical space; nonlinear and multidimensional space of society development, social events, social systems and their components; this is an anthroposphere which is supplemented by a "virtual" component of the inner world of human. Society creates a social space by its own way of life. It manifests itself through the triad: spatial practices - representations of space - spaces of representation. The whole concept of the production of social space is filled with communications and networks through which these communications take place. Humanity and its social space is a product of the communications that exist in it. Communication networks are the basis of the production and functioning of social space. To denote the processes of subjective transformation of social space and time, the following terms are used: time-space compression, space-time convergence, time-space distanciation, time-space expansion, friction of distance, distance decay. One of the main "tools" of space compression is the transportation network, and in recent decades, information and communication networks.

The question of the relationship between the concepts of "social space" and "geographical space" is relevant for geography. Geographical space contains elements of the social. At the same time, the majority of social processes have their own spatial expression. It is impossible to draw clear boundaries between geographical and social spaces. Their common construct "socio-geographical space" is increasingly used.
\end{abstract}

Key words: space, social space, production of space, geographical space, communications.

DOI: https://doi.org/10.17721/2413-7154/2020.84.4-12

UDC: $911.5 / 9: 30$

Received: October 30, 2020

Revised: December 14, 2020.

Accepted: December 23, 2020.

\section{СОЦІАЛЬНИЙ ПРОСТІР ЯК ОБ'ЄКТ ГЕОГРАФІЧНИХ ДОСЛІДЖЕНЬ ТА РОЛЬ КОМУНІКАЦІЙ У ЙОГО КОНСТРУЮВАННІ}

\section{Сергій ПУГАч}

Волинський національний університет імені Лесі Українки, м. Луцьк, Україна puhachserhiy@gmail.com

Анотація: У статті здійснено спробу аналізу поняття «соціальний простір» з позицій географічної науки. Географи традиційно розуміють простір як чисте полотно, на якому відбувається функціонування та розвиток людського суспільства. Проте вимоги сьогодення вимагають глибшого розуміння сутності людини, вивчення внутрішніх мотивів людської життєдіяльності. Для цього широко використовується категорія «соціальний простір». Метою даного дослідження $\epsilon$ систематизація наукових трактувань поняття «соціальний простір», визначення його властивостей та характерних рис у вітчизняній та зарубіжній науковій літературі. Головне завдання - визначення ролі комунікацій у формуванні та функціонуванні соціального простору.

Серед географів соціальний простір розуміється переважно як частина географічного простору, нелінійний і багатовимірний простір розвитку соціуму, соціальних подій, соціальних систем і їх складових; це антропосфера доповнена «віртуальною» складовою внутрішнього світу людських індивідів. Соціальний простір створює суспільство у рамках власного способу життєдіяльності. Він проявляється через тріаду: просторові практики - репрезентації простору - простори репрезентації. Уся концепція виробництва соціального простору пронизана комунікаціями та мережами, через які ці комунікації відбуваються. Людство та створюваний ним соціальний простір є продуктом комунікацій, які у ньому існують. Комунікаційні мережі $\epsilon$ основою виробництва та функціонування соціального простору. Для позначення процесів суб'єктивної трансформації соціального простору і часу використовують терміни: стиснення часу-простору, конвергенція простору-часу, дистанціонування часу-простору, розширення часу-простору, тертя простору, затухання з відстанню. Одним із головних «інструментів» стиснення простору $\epsilon$ транспортна мережа, а в останні десятиріччя й інформаційні комунікаційні мережі.

Актуальним для географії $\epsilon$ питання співвідношення понять «соціальний простір» та «географічний простір». Географічний простір містить у собі елементи соціального. Водночас, переважна більшість соціальних процесів мають свій просторовий вираз. Неможливо провести чітку межу між географічним та соціальним просторами. Усе частіше вживається їх спільний конструкт «соціально-географічний простір».

Ключові слова: простір, соціальний простір, виробництво простору, географічний простір, комунікації. 
Вступ. Вчені географи традиційно розуміють простір як чисте полотно (tabula rasa), на якому відбувається функціонування та розвиток людського суспільства. Це призводить до евклідового розуміння простору та спроб його осмислення за допомогою картографування економічних, політичних та соціальних процесів. Наприклад, у соціальній сфері розуміння географії як просторової науки призводить до намагань на основі даних переписів населення визначити території із схожим способом життя, ідентифікувати більш-менш однорідні соціальні ареали. Це часто призводить до спрощеного, поверхневого розуміння локальних соціумів на кшталт того, що усі люди в певній місцевості мають подібні соціальні характеристики. Більш індивідуально орієнтовані методи аналізу соціальних мереж показують, що індивідуальні світи окремих людей обертаються навколо локалізованого набору соціальних просторів. Часова географія, яку пов'язують 3 Т. Хагерстрандом та Лундською школою, запропонувала інший погляд на просторову соціальну практику, даючи деякі важливі вказівки щодо того, як соціальна діяльність розподілена в часі та просторі. 3 іншого боку, соціальна географія досліджує емоційні та навіть духовні зв'язки, що пов'язує суспільство 3 просторами, яким важко знайти однозначну територіальну ідентифікацію.

Сьогодні у соціально-економічній та географічній літературі широко використовується поняття «соціального простору». Ця категорія у науковому обігу з'явилася порівняно недавно, у 70-х pp. XX ст. Не дивлячись на значну поширеність терміну «соціальний простір», немає єдиного його трактування серед науковців. Особливо актуальним це питання є для представників географічної науки, для яких важливо не лише окреслити «просторові межі» соціального простору, а й визначити співвідношення між поняттями «соціальний простір» та «географічний простір».

Теоретико-методологічні основи дослідження. Спробам осягнути сутність соціального простору присвячена низка праць видатних науковців XX - початку XXI ст., таких як: П. Бурдьє, А. Гідденс, Д. Гарві, М. Кастельс, А. Лефевр, П. Сорокін та ін. Серед українських географів теоретичним проблемам соціального (соціально-географічного, соціально-економічного) простору належать праці Ю. Кисельова, Є. Маруняк, К. Нємця, Я. Олійника, А. Степаненка, О. Топчієва, О. Шаблія та ін. Проте, не зважаючи на багаточисленні спроби, відсутне єдине трактування поняття.

Мета і завдання дослідження. Головною метою дослідження $є$ систематизація наукових трактувань понять «соціальний простір», визначення його властивостей та характерних рис у вітчизняній та зарубіжній науковій літературі. Основним завданням - визначення ролі комунікацій у формуванні та функціонуванні соціального простору.

Виклад основного матеріалу. Для позначення обсягів функціонування людської спільноти вживаються терміни «соціальний простір», «суспільний простір», «простір суспільства», «простір життя людини», «простір соціальної діяльності» тощо. Ми ж для зручності об’єднаємо їх усіх під загальним терміном «соціальний простір».

У загальнонауковій методології принцип предметного простору добре відомий. Будь-яка множина об'єктів і явищ, між якими існують певні взаємодії та відношення, може розглядатися як предметний простір: . . . сукупність суспільних взаємин населення формує соціальний простір (Topchiiev, 2005, p. 166).

\section{Соціальний простір як наукова категорія}

Розглянемо основні визначення соціального простору у науковій літературі.

Соціальний простір охоплює як реальний фізичний світ, так і внутрішній світ людини, соціуму, людства в цілому. Про дуальну природу соціального простору наголошується у соціологічних працях. Так простір соичіальний - фундаментальна умова діяльності та спілкування людей у суспільстві. Простір соціальний охоплює два взаємозалежні рівні людської життєдіяльності: відношення людей до природи, що передбачає певну локалізацію історичних форм суспільства в географічному просторі природи (виділення наше), i рівень організації міжсуб'єктних, власне соціальних зв'язків, де просторовий момент співвідноситься 3 певними соціальними системами, характеризує упорядкованість множини соціальних подій та відносин, їх взаємокоординацію та субординацію, насиченість діяльністю та комунікацією, коли соціально-географічні параметри виступають похідними величинами суспільної інтеграції, значення яких транспоновані на землю (iї площі, територіальні розмежування і т.д.) (Volovych, 1998).

Положення людини у соціальному просторі визначається не лише її просторовими координатами а й соціальним статусом (місцем індивіда в соціальній групі, суспільстві). Вперше чітко цю позицію сформулював П. Сорокін: 1) соціальний простір - це народонаселення Землі; 2) соціальне становище - це сукупність його зв'язків з усіма групами населення, в середині кожної із цих груп, тобто із їі членами; 3) становище людини в соціальному всесвіті визначається шляхом встановлення цих зв'язків; 4) сукупність таких груп, а також сукупність становищ серед кожної із них становлять систему координат, що дає змогу визначити соціальне становище будь-якого індивіда (Sorokin, 1992, p. 299).

Соціальний простір у П. Бурдьє - абстрактна протяжність, конституйована ансамблем підпросторів або полів (економічне поле, інтелектуальне поле тощо), які зобов'язані своєю структурою нерівномірному розподілу окремих видів капіталу. Соціальний простір може сприйматися також у формі структури розподілу різних видів капіталу, яка функціонує одночасно як інструменти і цілі боротьби в різних полях. Реалізований фізично соціальний 
простір - це розподіл у фізичному просторі різних видів благ та послуг, а також індивідуальних агентів і груп, що локалізовані фізично і володіють можливостями привласнення цих благ та послуг (Bourdieu, 2005).

Соціальний простір - це не фізичний простір, але він намагається реалізуватися у ньому більш чи менш точно та чітко. Той простір, у якому ми живемо і який ми пізнаємо є соціально означеним та сконструйованим. Звідси П. Бурдьє робить висновок, що фізичний простір (реальний світ) це соціальна конструкція та проєкція соціального простору, соціальна структура в об'єктивованому стані, об'єктивація минулих та сучасних соціальних відносин (Bourdieu, 2005).

3 останнім твердженням важко погодитися, оскільки у формуванні фізичного простору бере участь не тільки людина. За таким суб'єктивним підходом перебільшується роль суспільства та другорядна роль відводиться природній складовій. Реальній світ (фізичний простір) може існувати і без участі людини.

Соціальний простір - це простір, освоєний людством у процесі його існування. Це $\epsilon$ частина фізичного простору, яка складає спосіб життєдіяльності суспільства, тобто олюднений простір. Він вписаний у простір біосфери. Соціальний простір є простором людського буття, який має перш за все соціально-культурний і духовно-практичний виміри. На відміну від фізичного простору, соціальний простір твориться самими людьми. Людина не перебуває в просторі, а організовує, структурує простір свого буття в культурі. Вона створює свій особистий простір, який вписаний у простір соціуму. Але разом 3 тим, відбувається автономізація, “приватизація" власного соціального простору. Соціальний простір має культурно-історичні межі, але й тенденцію до розширення: суспільство освоює все нові ділянки фізичного простору, окультурює їх, усуспільнює (Drotyanko et al., 2006).

3 точки зору М. Кастельса простір є виразом суспільства. У соціальній теорії його неможливо визначити без посилань на соціальну практику. Простір (соиіальний) є матеріальним продуктом по відношенню до інших матеріальних продуктів, включаючи людей, які задіяні в (історично) детерміновані соціальні відносини, що надають простору форму, функцію та соціальне значення. 3 точки зору соціальної теорії простір є матеріальною опорою соціальних практик розподілу часу (time sharing) (Castells, 1996).

Я. Олійник та А. Степаненко (2000) розуміють соичільний простір як багатовимірний простір, побудований за принципами диференціації i розподілу, сформований сукупністю діючих властивостей у соціальному універсумі (термін, що означає об'єктивну реальність у часі й просторі, множинність усіх можливих світів), тобто властивостей, що можуть дати його власнику силу і владу в цьому універсумі; це простір людського розвитку в масштабах суспільства як цілісної системи (Oliynyk \& Stepanenko, 2000, p. 66-67).
Тобто, у трактуванні соціального простору є два основні, 3 точки зору географії, підходи: 1) вузьке трактування - соціальний простір, як внутрішній світ людини, суспільства (щось на кшталт ментального, віртуального простору); 2) широке трактування соціальний простір, як загальний простір існування людства, поєднання фізичного (реального) простору із внутрішнім світом людини.

У середовищі географів соціальний простір розуміється переважно як частина географічного простру; простір розвитку соціуму, соціальних подій, соціальних систем і їх складових. Цей простір нелінійний i багатовимірний, його формалізація i аналіз потребують використання складного математичного апарату (Niemets \& Niemets, 2014, p. 14-15). Отже, образно кажучи соціальний простір - частина географічного простору доповнена «віртуальною» складовою внутрішнього світу людини та соціуму.

3 поняттям соціального простору фактично співпадає запропонований Ю. Кисельовим термін «людський геопростір», під яким автор розуміє геопростір, насичений антропологічним компонентом, інтегрованим у природне середовище, тобто сформований у результаті ландшафтноетнічної взаємодії (Kyseliov, 2011, р. 8). Він (тобто гепростір) не лише населений людськими спільнотами, а й такий, що відчувається та сприймається ними (Kyseliov, 2011, p. 49).

\section{Виробництво соціального простору}

Соціальний простір тісно пов'язаний iз життєдіяльністю людського суспільства. Він «створений» людьми для людей. Це перетворене згідно власних потреб навколишнє природнє середовище. В останні роки усе більшої популярності набуває концепція «виробництва простору», запропонована ще у 1974 р. французьким неомарксистом А. Лефевром. У своїй праці «Виробництво простору» (Lefebvre, 1991) він все оточуюче нас середовище називає соціальним простором. Цей простір $€$ “результатом нашарування ( взаємодіï) великої кількості спеціалізованих просторів (простір дозвілля, праці, ігровий, транспортний, соціальної інфраструктури, географічний, економічний, демографічний, соціологічний, екологічний, політичний, комерційний, національний, континентальний, світовий, простір природи (фізичний), потокові простори) і $€$ не що інше, як результат діяльності людини" (Lefebvre, 1991). Тобто, люди самі «створюють» та наповнюють своїй унікальні простори: "Немає одного соціального простору, є безкінечне різноманіття соціальних просторів: термін «соціальний простір» відсилає до їх незліченної множини." (Lefebvre, 1991). У рамках даної концепції простір розуміється не як щось стале та незмінне, а динамічний процес.

Кожен із нас розуміє, що мається на увазі, коли мова йде про «кімнату» у квартирі, «ріг» вулиці, «ринок», торговий чи культурний «центр», публічне «місце» тощо. Ці слова позначать різні соціальні простори, стосовно їх використання, тобто 
певної соціальної (i просторової) практики. Кожне суспільство у рамках даного способу виробництва формує свій простір за допомогою насильства (війни, революції), політичними та дипломатичними махінаціями, працею (Lefebvre, 1991) (звертає на себе увагу, що працю А Лефевр поставив лише на третє місце). Простір такого суспільство можна назвати «виробленим».

За А Лефевром, оскільки “суспільство створює соціальний простір, то це є не що інше, як соціальний продукт" (Lefebvre, 1991). Соціальній простір може бути створений (вироблений) лише людиною. Інакше він перестане бути соціальним.

Основа людського суспільства, те що нас робить людиною і відрізняє нас від тваринного світу - це наше спілкування, наші комунікації. Можна без перебільшення сказати, що комунікації приймають безпосередню i вагому участь у виробництві простору. Людській комунікації є основою існування соціальних мереж, що пройшли тривалий процес розвитку.

М. Маклюен (1964) розглядає медійний простір (простір комунікацій), як «розширення» у просторі людського тіла. Медійний простір пройшов наступні етапи розвитку: усна річ, письмо, книгодрукування, газети, радіо, телебачення (McLuhan, 1964). Глобальну мережу Інтернет можна розглядати як наступний етап еволюції комунікаційного простору людства. Соціальні інтернет-мережі, як одна із значних частин глобальної мережі Інтернет, приймають активну участь у виробництві сучасного соціального простору (Puhach, 2018, 2019b; Puhach, \& Poruchynsky, 2018). Причому сучасний соціальний простір завдяки їм все більше стає «віртуальним». Водночас простір природи (фізичний простір) все більше віддаляється від людини.

Сировина для виробництва соціального простору - це не якийсь окремий матеріал, як при виробництві окремих предметів; це сама природа, перетворена у продукт, забита, та яка знаходиться сьогодні під загрозою, можливо, зруйнована i, безумовно, локалізована (у цьому головний парадокс) (Lefebvre, 1991).

Функціонування соціального простору та комунікаційні мережі

Соціальний простір за А. Лефевром створюється i проявляється через тріаду «сприйняття (perceived) - осмислення (conceived) - переживання (lived)» (Lefebvre, 1991). В термінах простору - це: просторова практика - репрезентація простору - простори репрезентації (Bedash, 2012).

"Просторова практика будь-якого суспільства породжує свій простір; вона формує і пропонує його у діалектичній взаємодії: повільно, але вірно виробляє його, панує над ним і присвоює його собі. Аналіз виявляє просторову практику суспільства при дешифруванні його простору” (Lefebvre, 1991). Мова йде про процес виробництва матеріальної форми соціальних аспектів простору, про практики, що структурують соціальний простір. Наприклад, практики організації праці, дозвілля, політичної сфери та багато іншого. Просторові практики пов’язують між собою репрезентації простору та простори репрезентації.

Репрезентаціï простору, іншими словами, простір задуманий, простір вчених, планувальників, урбаністів, технократів, деяких художників (Lefebvre, 1991). Це те, як простір розуміється та інтерпретується професіоналами. До вказаних вище А. Лефевром фахівців без сумніву можна додати архітекторів, філософів, географів, інженерів, спеціалістів по міському та територіальному плануванню.

Простори репрезентаиії, тобто простір, який відчувається через супутні йому образи та символи; іншими словами, простір «жителів», «користувачів», а також окремих художників i, можливо, тих, хто описує - письменників, філософів (Lefebvre, 1991). Простори репрезентації - це «обжиті простори» (lived space). Мова йде про повсякденний досвід стосовно простору, який «скоріше відчувають ніж осмислюють» (Lefebvre, 1991)

Репрезентації простору (карти і плани, транспорт і зв'язок, образотворча і знакова інформація) постійно відсилають нас до простору репрезентацій (природи, родючості) у повсякденній практиці (Lefebvre, 1991).

Соціальні простори проникають один в одного та / або накладаються один на одного. Принцип взаємопроникнення та нашарування соціальних просторів містить один цінний момент: у кожному фрагментів простору, виділеному для аналізу, присутнє не один соціальний аспект, а їх множина (Lefebvre, 1991).

Створення та функціонування соціального простору відбувається внаслідок комунікацій, які існують у людському суспільстві. Людське спілкування, просторові переміщення індивідів, переміщення (перевезення) в просторі вантажів $\epsilon$ базисом для виникнення соціального простору. Соціальні інтернет-мережі, які сьогодні активно впливають і змінюють світ (соціальний простір загалом) якраз i $є$ одним із таких «Лефеврових» соціальних просторів. Вони активно впливають на соціальні просторові практики: ефекти стиснення простору, конвергенція простору, розширення простору. Простір сьогодні вже не є перешкодою для спілкування, якою він був колись.

Репрезентації простору, тобто «простір створений фахівцями», зараз все більше відбуваються через призму віртуальної реальності та кіберпростору. Відповідно і простори репрезентації сьогодення містять значну частку «віртуальної» комп'ютерної складової. Відбувається процес злиття реального світу та віртуальної реальності (Castells, 1996; Furashev, 2012; Galloway, 2004; McLuhan, 1964; Shtanko, 2012).

Як зазначалося вище, аналіз дозволяє виявити просторову практику суспільства при дешифруванні його простору. Сьогодні у повсякденному житті ми постійно натикаємося на знаки (символи) віртуального простору: знак зони Wi-Fi, комп'ютерний клуб (кафе), віртуальні реконструкції історичних об'єктів (наприклад фортеці Тустань), доповнена реальність та ін. 
Такі простори більше цінуються ніж звичайні навколишні.

\section{Сучасні просторові практики}

Сучасні просторові практики докорінно змінили сучасну економіку та ведення бізнесу. "Капітали перетікають у виробництво простору, залишаючи виробництво класичного типу - виробництво засобів виробництва (машин) чи споживчих благ" (Lefebvre, 1991).

3 розширенням капіталізму змінюється зміст поняття основного капіталу: воно вже означає не тільки промислове обладнання, приміщення та сировину. «Основний капітал очевидно включає в себе інвестиції у простір (шосе, аеродроми) та у різноманітну інфраструктуру. Хіба радарні мережі, які $є$ віхами у повітряному просторі, не володіють характеристиками основного капіталу? Перед нами засоби нового типу, далекими предками яких були дороги, канали, залізничні шляхи. Транспортні мережі виробничо споживаються, оскільки слугують для переміщення людей та речей у ланцюгах товарообігу, а також тому, що вони є інвестицією знання у соціальну реальність у масштабі всієї планети» (Lefebvre, 1991).

У сучасному світі можна навести дві великі групи прикладів перетікання капіталу у виробництво (соціального) простору:

1) стрімкий розвиток індустрії, що базується на мережі Інтернет, інформаційно-комунікаційних технологіях, створення віртуальної реальності (віртуального простору). Зараз це сфера економіки із оборотами у мільярди доларів.

2) усе частіше інвестується не окреме підприємство (засоби виробництва), а певна територія. Тобто, розвивається цілий регіон (BЕ3, CE3, Еврорегіон, виробничий кластер, рекреаційна зони та ін.). Вдалі інвестиції у одну галузь певної території тягнуть за собою капітали у інші сфери, тим самим інтенсифікуючи вироб-ництво простору. Прикладом можуть бути мережі готелів all inclusive у Туреччині та Єгипті. Вони виникли завдяки вкладанню капіталів у простір (у першу чергу рекреаційний) та сформовані завдяки інтенсивному розвитку комунікацій (у першу чергу авіаційного транспорту) останніх десятиліть. Зараз ці простори «обслуговують увесь світ».

Можна говорити, що сьогодні існує «ринок просторів». Одні країни є більш привабливими для інвестицій, інші - менш. Якщо у минулому основним інструментом захоплення простору були війни, то зараз - це економічна та культурна експансія, яку можна розглядати як засіб для захоплення простору мирним шляхом.

Ринок просторів існуе i на мікрорівні. "У минулому продавали чи брали у оренду земельну ділянку. Сьогодні купляють та продають об'єм: квартиру, житлове приміщення, кімнати, поверхи, тераси, різні елементи інфраструктури (басейн, тенісний корт, парковку)" (Lefebvre, 1991). Як це не парадоксально, але сучасна людина володіє не квартирою, а об'ємом простору на певній висоті, обмеженому стінами, підлогою та стелею. Без належної інфраструктури (виробленого простору) ця власність (квартира) втрачає будь-який сенс.

А. Лефевр продовжує характерну для ХХ ст. ідею єдності часу і простору: "Час пізнається та реалізується саме у просторі, через просторову практику. Простір, у свою чергу, пізнається у певному часі і через час" (Lefebvre, 1991). "Покупець є орендатором певної відстані, яка зв'язує його житло 3 різними локусами - центрами торгівлі, праці, дозвілля, культури, прийняття рішень. Тут на сцену знову виходить час, хоча простір, одночасно запрограмований та роздроблений, намагається його знищити як такий. ... Купляють проведення часу: використання часу $\epsilon$ споживчою вартістю даного простору. Проведення часу включає у себе приємності та неприємності, втрату та економію часу... Споживання простору набуває специфічних рис. Воно відрізняється від споживання речей... Простір вбирає у себе час" (Lefebvre, 1991).

Соціальний простір $\epsilon$ основою людського суспільства, його головним базисом. “«Змінити життя», «змінити суспільство» - усі ці слова не мають змісту, якщо немає виробництва відповідного простору" (Lefebvre, 1991). Справді, людина потрапивши у інший соціальний простір (наприклад за кордон) починає невпинно змінюватися. За два покоління внуки іммігранта стають повноцінними громадянами країни реципієнта, тобто повністю адаптованими («вписаними») у відповідний соціальний простір. 3 іншого боку, намагання привнести якийсь окремий елемент «чужого» простору у автохтонний, як правило закінчується повним фіаско.

Загалом, уся концепція виробництва соціального простору наскрізь пронизана комунікаціями та мережами, через які ці комунікації (у широкому розумінні, взаємодіiі) відбуваються. Людство та створюваний ним соціальний простір є продуктом комунікацій, які у ньому існують. Без комунікацій неможливо уявити соціум. Не випадково, у результаті воєн, супротивники найперше намагаються захопити комунікації: населенні пункти із сприятливим суспільно-географічним положення; під час перевороту 1917 р. більшовики найперше захоплювали вокзали (залізниці) та головпоштамти; сучасні гібридні війни у значній мірі відбуваються в інформаційному просторі. Комунікаційні мережі $€$ основою виробництва та функціонування соціального простору.

\section{Трансформації соціального простору}

Вважається, що вперше термін “стиснення простору” в наукову літературу ввів D. Harvey (1989). Дослідження цього явища має міждисциплінарний характер й чи не головне місце тут належить географічним наукам, зокрема суспільній географіï.

Говорячи про стиснення простору, ми маємо на увазі трансформації саме соціального простору, адже реальний фізичний простір під впливом людини змінюється порівняно мало: відстані, площі, об'єми лишаються незмінними. Змінюється лише відношення людини до них. 
Існує два головні види трактувань стиснення соціального простору: 1) зростання його проникності, зв'язаності, доступності; 2) скорочення заселених, освоєних, економічно активних земель (Treivish, 2010, p. 16). У першому випадку відбувається вдосконалення комунікаційної мережі та, як наслідок, виробництво соціального простру відбувається більш інтенсивно. У другому випадку - маємо зворотній процес згортання виробництва соціального простору та деградацію систем комунікацій.

Сучасний рівень науково-технічного прогресу, світові інтеграційні процеси, глобалізація, формування світових комунікаційних систем зумовлюють часове прискорення суспільного розвитку та ущільнення географічного простору (Pashynska, 2011). Мова йде про розуміння просторучасу, як виміру зусилля, яке докладається для подолання відстані. Таке трактування впритул наближається до понять транспортна доступність та ймовірні конкурентні переваги певного місця. Розуміння сутності стиснення географічного простору полягає переважно в технологічних зрушеннях у галузі транспорту та зв'язку, що збільшують мобільність капіталу, товарів, населення тощо. При цьому значення відстаней та місць нібито зменшується (Marunyak, 2012).

У західній літературі (Gregory et al., 2009; Kotlyakov \& Komarova, 2007; Warf, 2006; Witherick et al., 2001) для позначення процесів суб'єктивної трансформації соціального простору i часу використовують терміни «time-space compression» (стиснення часу-простору), «time-space convergence» (конвергенція простору-часу), «time-space distanciation» (дистанціонування часу-простору), «time-space expansion» (розширення часу-простору), «friction of distance» (тертя простору), «distance decау» (затухання з відстанню).

Стиснення часу-простору (time-space compression) - це зростання швидкості соціального життя та зменшення обмежуючих ефектів віддалі у людській діяльності (Gregory et al., 2009, p. 757).

Конвергенція часу-простору (space-time convergence) - зменшення часу переміщення між місцями (точками простору) та зниження важливості відстані, яке спричиняється вдосконаленнями у транспорті та комунікаціях (Witherick et al., 2001, p. 267).

Дистаниіонування часу-простору (time-space distanciation) - термін, запропонований англійським соціологом А. Гідденсом для опису «розширення» соціальних систем у просторі і часі (Giddens, 1984). Значного поширення не набув, але став передумовою для розвитку концепцій «стиснення часу-простору» та «конвергенція часу-простору».

Розширення часу-простору (time-space expansion) - концепція, яка $є$ наслідком або другою (протилежною) складовою концепції «стиснення часу-простору» (Gregory et al., 2009 , p. 760). Внаслідок розвитку транспорту i комунікацій людство спроможне подолати значно більші відстані. Відповідно, простір людської життєдіяльності не стиснувся, а навпаки розширився.

Для опису взаємодій у просторі застосовуються парні категорії «тертя простору» та «дистанція затухання».

Тертя простору (friction of distance) затримуючий вплив відстані на масу взаємодії між місцями (включаючи міграції, туристичні потоки, рух товарів та послуг, поширення ідей). Емпірична закономірність взаємодії патернів, що характеризується такою величиною, як дистанція затухання (Gregory et al., 2009, p. 264). Це базове географічне поняття, що стосується перешкод у русі, які виникають внаслідок просторового відокремлення між місцями (локаціями), об’єктами, людьми. Чим більша відстань між об’єктами - тим більше тертя простору, тим більші витрати на іï подолання за допомогою транспорту чи комунікацій (Witherick et al., 2001, p. 103).

Затухання 3 відстанню (distance decay) зменшення активності прояву явища чи процесу із збільшенням відстані від центральної точки (Gregory et al., 2009, p. 168). Послаблення взаємодії між двома об’єктами чи явищами внаслідок збільшення відстані чи зростання величини тертя простору.

Таким чином, під стисненням простору (географічного, соціального) розуміють процес скорочення витрат часу на подолання простору за рахунок віртуального зменшення масштабів i відстаней у результаті скорочення просторового розриву в комунікаціях і соціально-економічних процесах. Незважаючи на те, що фізична відстань не змінилася, її сприйняття у свідомості окремої людини і всього суспільства стало іншим. Фактично земний простір ущільнився в одну точку і доступність того чи іншого місця на Землі визначається не відстанню між пунктами, а транспортною або інформаційною доступністю (Pashynska, 2011).

Процес стиснення географічного простору можна розглядати на глобальному, регіональному, державному, обласному, локальному рівнях. Для регіональних і локальних рівнів важливе значення має транспортна доступність, розвиток швидкісної транспортної інфраструктури, зв'язність і мобільність транспортної мережі (Mironenko \& Sorokin, 2001).

Одним із головних «інструментів» стиснення простору $€$ транспортна мережа. Транспортна мережа - це реалізація просторової мережі (графу, елементами якого є просторові елементи), що відповідає структурі, де відбувається рух транспортних засобів або потоків вантажів (Barthelemy, 2011). Прикладами можуть бути автошляхи, залізниці, повітряні шляхи, водні шляхи, трубопроводи, водопроводи, лінії електропередач та ін. Вплив транспорту на ущільнення простору можна охарактеризувати наступними компонентами: скорочення часу чи вартості транспортних послуг, збільшення швидкості пересування, підвищення транспортної освоєності території.

За останні роки, внаслідок розвитку транспорту та комунікацій ефект тертя простору 
для транспортних потоків пасажирів та товарів, хоча і значно послабився, але все ще продовжує грати важливу роль. У випадку ЗМІ та соціальних інтернет-мереж тертя простору мінімальне. В ідеалі взаємодія мала б охопити увесь світ. Проте, як і 3 матеріальними об'єктами, спостерігається певна величина дистанції затухання - зниження взаємодії iз зростанням відстані.

Takhteyev, Gruzd, \& Wellman (2012) на прикладі географії соціальної інтернет-мережі Twitter показали, що на інтенсивність контактів найбільше впливають: 1) географічна відстань, 2) національні кордони, 2) мова спілкування співрозмовників, 4) частота авіаперевезень. Тобто iз 4 основних чинників 3 мають чітко виражений просторовий характер. Тобто, простір нікуди не зник, а продовжує відігравати важливу роль навіть у віртуальному світі соціальних он-лайн мереж.

Науково-технічний прогрес останніх років лише підтвердив перший закон географії В. Тоблера «Усе пов'язано з усім рештою, але близькі об’єкти зв’язані тісніше ніж віддалені» (Tobler, 1970).

Соціальні інтернет-мережі відіграють велику роль у стисненні соціального простору. Соціальний простір стискається до точки, виникає можливість безпосередньої взаємодії 3 людьми безвідносно їхнього просторового розміщення, соціум формується як «глобальне село» (McLuhan, 1964) - на основі безпосередніх, міжособистісних, неформалізованнх відносин між індивідами, які позбавлені макрогрупового впливу. Базовою соціальною групою у суспільстві ймовірно буде місцева громада, а основними суб'єктами соціальних дій - представники інформаційного, банківського i фінансового капіталу, що набувають нового, електронного вигляду (Afanasyev, 2017, p. 120).

Висновки та дискусія. Отже, поняття «соціальний простір»є важливим для географії не тільки 3 теоретичної точки зору, а і як важливий методологічних підхід до вивчення внутрішнього світу суспільства. У трактуванні соціального простору $є$ два основні підходи: 1) вузьке трактування - соціальний простір, як внутрішній світ людини, суспільства (щось на кшталт віртуального простору); 2) широке трактування соціальний простір, як загальний простір існування людства, поєднання фізичного (реального) простору із внутрішнім світом людини.

У середовищі географів соціальний простір розуміється переважно як частина географічного простору, нелінійний i багатовимірний простір розвитку соціуму, соціальних подій, соціальних систем і їх складових; це антропосфера доповнена «віртуальною» складовою внутрішнього світу людських індивідів.

В останні роки усе більшої популярності набуває концепція виробництва соціального простору А. Лефевра, згідно якої кожне суспільство у рамках власного способу життєдіяльності формує свій простір. Комунікації приймають безпосередню i вагому участь у виробництві простору. Соціальний простір створюється і проявляється через тріаду просторові практики репрезентації простору - простори репрезентації. За допомогою аналізу можна виявити просторову практику суспільства при дешифруванні його простору.

Уся концепція виробництва соціального простору наскрізь пронизана комунікаціями та мережами через які ці комунікації відбуваються. Людство та створюваний ним соціальний простір $\epsilon$ продуктом комунікацій, які у ньому існують. Комунікаційні мережі $є$ основою виробництва та функціонування соціального простору.

Для позначення процесів суб'єктивної трансформації соціального простору i часу використовують терміни стиснення часу-простору, конвергенція часу-простору, дистанціонування часу-простору, розширення часу-простору, тертя простору, затухання з відстанню. Одним із головних «інструментів» стиснення простору є транспортна мережа, а в останні десятиріччя й інформаційні комунікаційні мережі.

Надзвичайно актуальним для географії $\epsilon$ питання співвідношення понять «соціальний простір» та «географічний простір» (Puhach, 2019a, 2019b). Географічний простір містить у собі елементи соціального. Наприклад, одне iз центральних понять суспільної географії суспільно-географічне положення - $є$ конструктом як географічного, так і соціального просторів та має чітко виражений соціальний контекст. Водночас, переважна більшість соціальних процесів мають свій територіальний (просторовий) вираз.

Koch (2005) проводить наступний приклад: соціальний простір (social systems) - це сім'я, геопростір (spatial systems) - це будинок (квартира). Будь-яка спроба провести чітко визначені паралелі між ними приречена на невдачу. Сім'я не проводить увесь свій час у квартирі; сім'я може мати кілька квартир; окремі члени сім’ї можуть проживати окремо та ін. Водночас, в одному будинку можуть проживати кілька сімей; будинки (приміщення) можна використовувати не тільки для проживання, а і як офіси, виробничі приміщення тощо. У результаті виникає гідридний простір який одночасно $\epsilon$ віртуальним та реальним, соціальним та територіальним (локалізованим). Між складовими такого простору неможливо провести чітких меж, а для аналізу таких систем (просторів) необхідні принципово нові методологічні підходи.

Схожих поглядів дотримуються й українські географи. Сьогодні усе частіше вживається не окремо терміни «географічний простір» та «соціальний простір», а їх спільний конструкт. Так Я. Олійник та А. Степаненко вживають термін «соціально-географічного простір» (Oliynyk \& Stepanenko, 2000, p. 56). С. Маруняк пропонує розглядати «соціально-економічний простір» (Marunyak, 2012, p. 40). К Нємець - «суспільногеографічний простір» (Niemets \& Niemets, 2014, p. 26). 
На жаль грунтовних праць щодо співвідношення концепцій геопростору та соціального простору в українській географії є дуже мало. Переважно це окремі аспекти даного питання у працях, які присвячені іншим проблемам. У наш час коли йде інтенсивний наступ на географію зі сторони інших наук, географам варто було б активніше розробляти концепцію соціального простору, особливо у тї взаємозв'язках та взаємодіях не лише із географічних простором, а й $з$ віртуальними просторами, такими як кіберпростір, простір соціальних он-лайн мереж тощо.

\section{References:}

Afanasyev, D. (2017). Formation of social potential of Internet communities (on an example of Zakarpatia region). $\mathrm{PhD}$ Thesis. Uzhhorod: Uzhhorod National University. [In Ukrainian]. [Афанасьєв Д. М. Формування соціального потенціалу Інтернет-спільнот (на прикладі Закарпатської області) : дис. ... канд. соц. наук : 22.00.04. Ужгород, 2017. 215 c.]

Barthelemy, M. (2011). Spatial Networks. Physics Reports, 499, 1-101. http://arxiv.org/abs/1010.0302

Bedash, Yu. (2012). Henri Lefebvre's concept of social space. TSPU Bulletin, 11 (126), 219-224. [In Russian]. [Бедаш Ю. А. Концепция социального пространства Анри Лефевра. Вестник ТГПУ. 2012. № 11 (126). С. 219 224.]

Bourdieu, Р. (2005). Social space: fields and practices. St. Petersburg: Aleteya. [In Russian]. [Бурдье П. Социальное пространство: поля и практики : Пер. с фр. Санкт-Петербург: Алетейя, 2005. 576 с.]

Castells, M. (1996). Information Age. Vol. l. The Rise of the Network Society. Oxford: Blackwell Publishers.

Drotyanko, L., Matyukhina, O., \& Vdovychenko, V. (2006). Workshop on philosophy: textbook. Kyiv: Knyzhkove vydavnytstvovo NAU. [In Ukrainian]. [Практикум з філософії : навч. посібник / Л. Г. Дротянко, О. А. Матюхіна, В. Г. Вдовиченко та ін. Київ: Книжкове видавництвово НАУ, 2006. 232 с.]

Furashev, V. (2012). Cyberspace and information space, cybersecurity and information security: essence, definitions, differences. Information and law, 2(5), 162-175. [In Ukrainian]. [Фурашев В. М. Кіберпростір та інформаційний простір, кібербезпека та інформаційна безпека: сутність, визначення, відмінності. Інформація і право. 2012. № 2 (5). С. 162-175.]

Galloway, A. (2004). Intimations of everyday life: ubiquitous computing and the city. Cultural Studies, 18 (2/3), 384-408. DOI: 10.1080/0950238042000201572

Giddens, A. (1984). The constitution of society: out line of the theory of structuration. Cambridge: Polity Press. London: Macmillan.

Gregory, D., Johnston, R., Pratt, G., Watts, M., \& Whatmore, S. (eds.) (2009). The Dictionary of Human Geography. 5th Edition. Chichester: Wiley Blackwell.

Harvey, D. (1989). The Condition of Postmodernity: An Enquiry into the Origins of Cultural Change. Cambridge, MA: Blackwell.

Koch, A. (2005). Autopoietic spatial systems: the significance of actor network theory and system theory for the development of a system theoretical approach of space. Social Geography, 1, 5-14. DOI: 10.5194/sg-1-5-2005.

Kotlyakov, V., \& Komarova, A. (eds.) (2007). Elsevier's Dictionary of Geography in English, Russian, French, Spanish and German. Amsterdam - Boston - Heidelberg - London - New York - Oxford Paris - San Diego - San Francisco - Singapore - Sydney - Tokyo : Elsevier.

Kyseliov, Y. (2011). Fundamentals of geosophy: problems of theory and methodology. Luhansk: Vydavnytstvo DZ «LNU imeni Tarasa Shevchenka». [In Ukrainian]. [Кисельов Ю. О. Основи геософії : проблеми теорії та методології. Луганськ: Видавництво ДЗ «ЛНУ імені Тараса Шевченка», 2011. 208 с.]

Lefebvre, H. (1991). The Production of Space (Translated by D. Nicholson-Smith). Wiley-Blackwell.

Marunyak, E. (2012). Globalization spatial dilemmas and their conceptualization. Ukrainian Geographical Journal, 4, 36-42. [In Ukrainian]. [Маруняк Є. О. Просторові дилеми глобалізації та їх концептуалізація. Украӥнський географічний журнал. 2012. № 4. С. 36-42.]

McLuhan, M. (1964). Understanding media: the extensions of man. New York: McGraw Hill.

Mironenko, N., \& Sorokin, M. (2001). Factors of compression of geographic space. Geography, 48, 4-6. [In Russian]. [Мироненко Н. С., Сорокин М. Ю. Факторы сжатия географического пространства. География. 2001. № 48. C. 4-6.]

Niemets, K., \& Niemets, L. (2014). Theory and methodology of geography: spatial analysis methods. Kharkiv: V. N. Karazin Kharkiv National University. [In Ukrainian]. [Нємець К. А., Нємець Л. М. Теорія і методологія географічної науки: методи просторового аналізу / Навчально-методичний посібник. Харків: ХНУ імені В. Н. Каразіна, 2014. 172 c.]

Oliynyk Ya., \& Stepanenko A. (2000). Introduction to social geography: textbook. Kyiv: Znannia. [In Ukrainian].

[Олійник Я. Б., Степаненко А. В. Вступ до соціальної географії : навч. посіб. Київ : Знання, 2000. 204 с.]

Pashynska, N. (2011). Transport factor in the compression of geographical space. Scientific notes of V.I. Vernadsky Tauride National University, 24(63), 2, 3, 204-208. [In Russian]. [Пашинська Н. М. Транспортний чинник у стисненні географічного простору. Ученые записки Таврического национального университета им. В. И. Вернадского. 2011. Т. 24 (63). №2. Ч. 3. С. 204-208.]

Puhach, S. (2018). Using concepts of geographical and social spaces in study of social networking services. In 
Geography in Taras Shevchenko National University of Kyiv: 85 years - achievements and prospects (GTSNU) (pp. 171-173). Kyiv: Print-Service. [In Ukrainian]. [Пугач С. О. Використання концепцій географічного та соціального простору у дослідженнях соціальних мереж. Географія в Київському наиіональному університеті імені Тараса Шевченка: 85 років - досягнення та перспективи (GTSNU) : матеріали міжнародної науково-практичної конференції (м. Київ, 30-31 березня 2018 р.). Київ: Прінт-Сервіс, 2018. С. 171-173.]

Puhach, S. (2019a). Conceptualization of the concept of geographical space in the scientific literature. Ekonomichna ta Sotsialna Geografiya, 82, 27-33. DOI: 10.17721/2413-7154/2019.82.27-33 [In Ukrainian]. [Пугач C. Концептуалізація поняття географічний простір у науковій літературі. Економічна та соціальна географія. 2019. № 82. C 27-33.]

Puhach, S. (2019b). Geographic information systems as social networking services. In Tourism, Geography, Local History: current issues of theory and practice (pp. 192-195). Ternopil: RVV TNPU im. V. Hnatyuka. [In Ukrainian]. [Пугач С. Геоінформаційні системи, як соціальні мережі. Туризм, географія, краєзнавство : актуальні проблеми теорії і практики : Матеріали міжнародної науково-практичної конференції (м. Тернопіль, 16-17 травня 2019 р.). Тернопіль: РВВ ТНПУ ім. В. Гнатюка, 2019. С. 192-195.]

Puhach, S., \& Poruchynsky, V. (2018). Geospatial aspects of development and functioning of social networking services. In O. Shabliy (ed.) Social geography: scientific traditions and modern challenges (pp. 83-86). Lviv: Ivan Franko Lviv National University. [In Ukrainian]. [Пугач С., Поручинський В. Геопросторові аспекти розвитку та функціонування соціальних мереж. Суспільна географія : наукові традиції і сучасні виклики : матеріали Всеукраїнського наукового семінару (м. Львів, 13 грудня 2018 р.). Львів: ЛНУ імені Івана Франка, 2018. C. 83-86.]

Shtanko, V. (2012). Virtual communicative space and problems of self-identification. Bulletin of V.N. Karazin Kharkiv National University. Series: Theory of Culture and Philosophy of Science, 1029 (1), 47, 5-12. [In Ukrainian]. [Штанько В. І. Віртуальний комунікативний простір і проблеми самоідентифікації особистості. Вісник Харківського національного університету імені В. Н. Каразіна. Серія: Теорія культури і філософія науки. 2012. № 1029 (1). Вип. 47. С. 5-12.]

Sorokin, P. (1992). Human. Civilization. Society. Moscow: Politizdat. [In Russian]. [Сорокин П. А. Человек. Цивилизация. Общество. Москва: Политиздат, 1992. 543 с.]

Takhteyev, Y., Gruzd, A., \& Wellman, B. (2012). Geography of Twitter networks. Social Networks, 34 (1), $73-81$. doi:10.1016/j.socnet.2011.05.006.

Tobler, W. A. (1970). Computer Movie Simulating Urban Growth in the Detroit Region. Economic Geography, 46, 234-240.

Topchiiev, O. (2005). Socio-geographical research: methodology, methods, techniques: Textbook. Odesa: Astroprynt. [In Ukrainian]. [Топчієв О. Г. Суспільно-географічні дослідження: методологія, методи, методики: навч. посібник. Одеса: Астропринт, 2005. 632 с.]

Treivish, A. (2010). "Compression" of space: interpretations and models. In Compression of socio-economic space: new in the theory of regional development and the practice of its state regulation (pp. 16-31). Moscow: Eslan. [In Russian]. [Трейвиш А. И. «Сжатие» пространства: трактовки и модели. Сжатие сочиально-экономического пространства: новое в теории регионального развития и практике его государственного регулирования. Москва: Эслан, 2010. С. 16-31.]

Volovych, V. (ed.) (1998). Sociology: a short encyclopedic dictionary. Kyiv: Ukrayins'kyy Tsentr dukhovnoyi kul'tury. [In Ukrainian]. [Соціологія : короткий енциклопедичний словник / під заг. ред. В. І. Воловича. Київ: Український Центр духовної культури, 1998. 736 с.]

Warf, B. (ed.) (2006). Encyclopedia of Human Geography. London - New Deli: SAGE Publications.

Witherick, M., Ross, S., \& Small, J. (2001). A Modern Dictionary of Geography. 4th Edition. London: Arnold. 